INSTITUT AGAMA ISLAM IMAM GHOZALI (IAIIG) CILACAP

LPPM (Lembaga Penelitian dan Pengabdian Masyarakat)

Al-Munqidz : Jurnal Kajian Keislaman

Jl. Kemerdekaan Barat No.17 Kesugihan-Cilacap || https://ejournal.iaiig.ac.id/index.php/amk Issn SK no. : 0005.235/JI.3.2/SK.ISSN/2012.07 || 0005.27158462/JI.3.1/SK.ISSN/2020.01

\title{
LIVING QURAN: RESEPSI AL-QUR'AN DI PONDOK PESANTREN AL-HUSNA DESA SIDOREJO PAMOTAN REMBANG
}

\author{
Nur Huda ${ }^{1}$, Athiyyatus Sa'adah Albadriyah ${ }^{2}$ \\ Sekolah Tinggi Agama Islam Al-Anwar Rembang ${ }^{1}$ Alumni UIN Walisanga Semarang ${ }^{2}$ \\ email: nurhuda@staialanwar.ac.id ${ }^{1}$, nokada1991@ @mail.com ${ }^{2}$
}

Naskah Diterima

27 Agustus 2020

Publis Artikel

7 September 2020
Abstract: This study aims to analyze the al-Qur'an reception at AlHusna Islamic Boarding School Sidorejo Pamotan Rembang. This research is a qualitative research using inductive descriptive method. Qualitative research is a research procedure that analyzes descriptive data in the form of speech or written observations. Inductive descriptive method aims to describe and analyze data to obtain a general description or description of the al-Qu'ran reception at Al-Husna Islamic Boarding School. This research confirms that the Qur'an is a holy book that is always in harmony with all situations and conditions (șälih li kulli zamān wa makān). The theory used by the researcher here is Karl Mannheim's sociological theory of meaning, which focuses on three typologies of meaning, namely objective, expressive, and documentary meanings. This study yielded at least two findings. First, there were several types of receptions at the Al-Husna Islamic Boarding School. Second, the meanings inherent in the reception include, a) objective meaning, that the variety of reception behavior at AlHusna Islamic Boarding School is part of a symbol of obedience and disbelief towards the pondok regulations, b) the meaning of expression is manifested in the form of selfinternalization with values positive values in the continuous learning process of the Koran, and c) documentary meaning is manifested in the form of local contextualization of a comprehensive cultural system.

\section{Keywords : Receptions, Al-Qur'an, Al-Husna, Meanings}

Abstrak Penelitian ini bertujuan untuk menganalisa resepsi alQur'an di Pondok Pesntren Al-Husna Sidorejo Pamotan Rembang. Penelitian ini merupakan penelitian kualitatif dengan menggunakan metode deskriptif induktif. Penelitian 
alitatif merupakan salah satu prosedur penelitian yang menganalisis data deskriptif berupa tuturan atau tulisan observasi. Metode deskriptif induktif bertujuan untuk mendeskripsikan dan menganalisis data untuk mendapatkan gambaran umum atau deskripsi tentang resepsi al-Qu'ran di Ponpes Al-Husna. Penelitian ini menegaskan bahwa al-Qur'an merupakan kitab suci yang senantiasa selaras dengan segala situasi dan kondisi (șāliḥ li kulli zamān wa makān). Teori yang digunakan peneliti di sini adalah teori sosiologi makna Karl Mannheim dengan menitikberatkan pada tiga tipologi makna, yakni makna objektif, eksprwsif, dan dokumenter. Penelitian ini menghasilkan setidaknya dua temuan. Pertama, ditemukan beberapa ragam resepsi di Ponpes Al-Husna. Kedua, maknamakna yang melekat dalam resepsi tersebut antara lain, a) makna objektif, bahwa ragam perilaku resepsi di Ponpes AlHusna adalah bagian dari simbol kepatuhan dan ketakdziman terhadap peraturan pondok, b) makna ekspresi diwujudkan dalam bentuk internalisasi diri dengan nilai-nilai positif dalam proses pembelajaran al-Qur'an yang berkelanjutan, dan c) makna dokumenter diwujudkan dalam bentuk kontekstualisasi lokal dari sistem budaya yang menyeluruh.

\section{Kata Kunci : Resepsi, Al-Qur'an, Al-Husna, Makna}

\section{A. Pendahuluan}

Selain berfungsi sebagai pedoman, al-Qur'an juga memiliki fungsi-fungsi lain yang menjadi keyakinan masyarakat muslim. Di antara fungsi itu adalah bahwa al-Qur'an merupakan obat dan penyelamat dari mara bahaya. Ia juga merupakan spirit perubahan, pembela kaum marjinal, penentang tindakan lalim, dan masih banyak lagi menyesuaikan kebutuhan masyarakat. Sehingga masyaraka muslim mentrasformasikan teks al-Quran dan berdialektika secara langsung yang dengan sendirinya alQur'an menjadi menjadi bernilai dan hidup di tengah-tengah mereka ${ }^{1}$.

Interaksi aktif dengan al-Qur'an merupakan hal yang tidak bisa dipungkiri lagi bagi masyarakat muslim. Bahkan interaksi tersebut merupakan keharusan bagi mereka sebagai wujud ketaatan dalam beragama. Bentuk interaksi itu bisa diwujudkan dengan cara membaca, menelaah, tadabbur, dan bahkan terkadang diamalkan sesuai pemahaman masing-masing masyarakat.

Al-Qur'an sering disebut sebagai kitab suci yang fleksibel, Săliḥ fi Kulli Zamān wa Makān, artinya ia senantiasa selaras dengan situasi dan kondisi. Indikasi keselarasan tersebut

\footnotetext{
${ }^{1}$ Farid Esack, The Qur'an: A Short Introduction (England: Oneworld, 2002), hlm. 15-17.
} 
salah satunya bisa dilihat bagaimana ekspresi dan resepsi masyarakat muslim terhadap keberadaan al-Qur'an di tengah-tengah mereka. Hal ini merupakan bagian dari pegerseran paradigma yang pada awalnya al-Qur'an merupakan kitab suci berisi ajaran-ajaran moral untuk menunutun manusia ke jalan yang benar, namun belakangan diekpresikan dan diresepsi sesuai dengan pengetahuan dan pemahaman masing-masing.

Dalam konteks meresepsi al-Qur'an, keluarga besar Pondok Pesantren Al-Husna Sidorejo Pamotan Rembang merupakan salah satu pesantren yang melestarikan resepsi tersebut. Misalnya saja kegiatan tradisi pembacaan surah al-Wāqiah, surah Yāsīn, dan surah alMulk di pesantren yang dulu desanya bernama Njumput itu. Pembacaabn surah al-Wāqi'ah merupakan rutinitas santri Al-Husna yang dilakukan selesai shalat isya' berjamaah, surah Yāsīn rutin dibaca setelah shalat maghrib, sementara surah al-Mulk biasa dibaca santri setelah shalat subuh. Tradisi ini dilakukan secara kolektif dan berjamaah dipimpin langsung oleh pengasuh atau santri yang kebetulan ditunjuk pengasuh untuk menjadi imam ${ }^{2}$.

Hal menarik lain yang bisa diangkat pada penelitian kali ini adalah bahwa santri melakukan resepsi al-Qur'an yakni menjadikan kaligrafi yang diletakkan di berbagai tempat, seperti di asrama putri dan di dalêm pengasuh ${ }^{3}$. Selain itu, resepsi lain di pesantren ini adalah pengajian rutin Tafsīr Jalālain dan kegiatan simā'an atau murāja'ah.

Penelitian ini bertujuan untuk mengetahui ragam dan varian resepsi al-Qur'an di Pondok Pesantren Al-Husna Sidorejo Pamotan Rembang serta berusaha memahami makna yang melekat di dalamnya.

Sejatinya penelitian resepsi dan living Qur'an sudah banyak diteliti. Sebut saja penelitian Luthfiaus Shobahah (2017) tentang Praktik Pembacaan Yasin Fadilah Di Masyarakat Perspektif Living Qur'an dan Analisis Perubahan Sosial (Studi Kasus di Majelis Taklim Al-Muthmainnah Desa Lemahabang Kulon, Kec. Lemahabang, Kab. Cirebon $)^{4}$. Artikel Elly Magfiroh (2017) $)^{5}$ yang berjudul Living Qur'an : Khataman sebagai Upaya Santri dalam Melestarikan Al-Qur'an, Abdullah Afandi dan Ummu Malihatur Roihana (2018) dengan judul

\footnotetext{
${ }^{2}$ Pujiono, Wawancara Santri, Sidorejo, 20 Agustus, 2020.

${ }^{3}$ Nur Huda, Observasi Dan Pengamatan, Sidorejo, 18 Agustus 2020.

${ }^{4}$ Luthfiatus Shobahah, 'Praktik Pembacaan Yasin Fadilah Di Masyarakat Perspektif Living Qur'an Dan Analisis Perubahan Sosial (Studi Kasus Di Majelis Taklim Al-Muthmainnah Desa Lemahabang Kulon, Kec. Lemahabang, Kab. Cirebon)', Diya Al-Afkar: Jurnal Studi Al-Quran Dan Al-Hadis, 5.02 (2017), 315-38.

5 Elly Maghfiroh, 'Living Qur'an: Khataman Sebagai Upaya Santri Dalam Melestarikan Al-Qur'an', Hermeneutik: Jurnal Ilmu Al-Qur’an Dan Tafsir, 11.1 (2017), 109-27.
} 
Tradisi Pembacaan Surah Munjiyat di Ponpes Al-Hikmah Kediri : Kajian Living Qur'an, dan Abdul Fatah $^{6}$ (2020) yang berjudul Living Qur'an: Tradisi Wirid Al-Ma’tsūrāt Di Smait Abu Bakar Boarding School Kulon Progo.

Beberapa penelitian di atas secara lingkup material maupun formal berbeda dengan penelitian kali ini. Hal itu dikarenakan bahwa peneliti fokus menggunakan teori sosiologi Karl Mannheim untuk menjawab penarian makna melalui tiga variabel, yakni makna objektif, makna ekpresif dan makna dokumenter.

\section{B. Landasan Teori}

a) Resepsi al-Qur'an dan Makna yang Melekat dalam Perspektif Epistimologis

Secara etimologi, resepsi merupakan salah satu kata yang berasal dari bahasa latin, recipere, yang memiliki arti penyambutan atau penerimaan pembaca ${ }^{7}$. Sementara resepsi secara terminologi adalah respon yang dilakukan oleh pembaca terhadap sebuah karya sastra. $^{8}$

Awal mula kemunculan teori resepsi adalah tanggapan pembaca terhadap karya sastra. Tujuannya adalah untuk memperoleh penilaian dari para penikmat dan konsumen karya sastra. Dalam praktiknya, pembaca menentukan makna dan nilai sehingga karya tersebut benar-benar memiliki nilai dari respon pembaca atau penikmat karya sastra. Dengan demikian, teori resepsi ini merupakan teori yang mengkaji tentang kontribusi atau feedback pembaca dalam menyambut sebuah karya sastra. ${ }^{9}$

Dalam konteks al-Qur'an, teori tersebut dapat difahami sebagai sebuah kajian yang merupakan respon pembaca terhadap ayat-ayat di dalam al-Qur'an. Ragam respon dan sambutan tersebut bisa berupa a) cara masyarakat muslim menafsirkan ayat-ayat al-Quran, b) cara masyarakat muslim mengimplementasikan nilai dan ajaran al-Qur'an, dan c) cara masyarakat muslim membaca dan melantunkan al-Qur'an. Dengan demikian dalam kajian kali ini terjadi dialektika, interaksi, dan resepsi terhadap al-Qur'an. Pada akhirnya, kajian

\footnotetext{
${ }^{6}$ Abdul Fatah Fatah, 'Living Qur'an: Tradisi Wirid Al-Ma'tsūrāt Di Smait Abu Bakar Boarding School Kulon Progo', Jurnal At-Tibyan: Jurnal Ilmu Alqur'an Dan Tafsir, 5.1 (2020), 1-19. 2011), hlm. 22.

Nyoman Kuta Ratna, Teori Dan Metode Teknik Penelitian Sastra, 8th edn (Yogyakarta: Pustaka Pelajar,

${ }^{8}$ Rachmad Djoko Pradopo, Beberapa Teori Sastra : Metode Sastra Dan Penerapannya (Yogyakarta: Pustaka Pelajar, 2007), hlm. 7.

${ }^{9}$ Wolfgang Iser, The Act of Reading : A Theory of Aesthetic Response (Baltimore: John Hopkins University Press, 1979), hlm. 20.
} 
ini akan memberi sumbangsih dalam mendeskripsikan tipologi masyarakat yang berinteraksi dengan al-Qur'an.

Sebuah karya dianggap sebagai sebuah karya sastra paling tidak harus memenuhi tiga unsur: ${ }^{10}$ 1) Estetika rima dan irama, 2) Defamiliarisasi, yakni ketertakjuban atau kekaguaman yang secara psikologis dirasakan oleh pembaca setelah mengkonsumsi karya tersebut, 3) Reinterpretasi, yakni rasa ingin tahu atau kuriositas pembaca untuk menginterpretasi ulang karya sastra yang telah dibaca.

Al-Qur'an yang merupakan kitab suci agama Islam merupakan salah satu bacaan masyarakat muslim yang bermediakan bahasa Arab yang banyak ditemukan unsur-unsur tersebut. Misalnya saja unsur estetika rima dan irama bisa dijumpai pada surah mu'awwidzataīn. Keindahan unsur tersebut secara tidak langsung mempengaruhi pembaca dan pendengarnya ${ }^{11}$. Sementara dalam ranah defamiliarisasi, secara otomatis pembaca dibuat kagum pada al-Qur'an atau ayat-ayat yang tersebar dalam al-Qur'an. Meminjam istilah Sayyid Qutb, masḥūrun bi al-Qur'ān, orang-orang 'tersihir' oleh keindahan alQur'an secara redaksional maupun isi dan makna. Hal itu pernah juga dialami oleh sahabat Umar bin Khatthab ketika mendengar adiknya membacakan salah satu surah dalam alQur'an. ${ }^{12}$

Unsur reinterpretasi juga memiliki kedudukan khusus oleh pembaca dan penikmat al-Qur'an dalam kehidupan nyata. Artinya, pembaca merespon secara langsung al-Qur'an tersebut untuk kemudian mengkaji aspek estetika, retotika, dan aspek lain yang melahirkan sikap, perilaku, tradisi, dan budaya yang merupaan wujud nyata pemahaman masyarakat muslim terhadap al-Qur'an.

Kajian resepsi, sebagaimana dikatakan oleh Ahmad Rafiq, termasuk kajian fungsi, yakni fungsi informatif dan dan fungsi performatif. Fungsi yang pertama menunjukkan bahwa al-Qur'an merupakan kitab suci yang dibaca, dipahami, dan diaplikasikan.

10 Fathurrosyid Fathurrosyid, 'Tipologi Ideologi Resepsi Al Quran Di Kalangan Masyarakat Sumenep Madura', EL HARAKAH Jurnal Budaya Islam, 17.2 (2016), 218-39.

${ }^{11}$ Nur Huda, 'Uslub Al-Tikrar Fi Surah Al-Mu'awwidzatain', Indonesian Journal of Islamic Literature and Muslim Society, 5.1 (2020), 1-13.

${ }^{12}$ Al-Baihaqi, Dalail Al-Nubuwwah (Kairo: Dar al-Kutub al-Ilmiyyah, 1986), II. hlm. 199. 
Sementara fungsi kedua, al-Qur'an dipakai dan diperlakukan sebagai wirid atau deresan bahkan suwuk bagi sebagian masyarakat muslim ${ }^{13}$.

Selain itu, Rafiq juga menyatakan bahwa lembaga keagamaan, termasuk di dalamnya pondok pesantren lebih sering melakukan kajian al-Qur'an dalam ranah fungsi performatif. Hal itu bisa dianalisa melalui tiga tipologi berikut $\mathrm{ini}^{14}$ :

1. Resepsi Eksegegis

Dikatakan sebagai resepsi eksegegis ketika masyarakat memposisikan alQur'an sebagai teks yang berbahasa Arab dan bermakna sebagai bahasa. Wujud dari resepsi ini paling tidak ada dua. Pertama, wujud penafsiran al-Qur'an secara lisan, yakni al-Qur'an ditafsirkan melalui pengajian-pengajian kitab tafsir seperti kajian tafsir Jalālǟn, tafsir Ibnu Kas̀ìr, dan tafsir-tafsir lainnya. Kedua, penafsiran al-Qur'an dengan tulisan (bi al-qalam), yakni al-Qur'an ditafsirkan melalui banyak karya tafsir.

2. Resepsi Estetis

Dalam konteks resepsi ini, al-Qur'an dipandang sebagai sebuah teks kitab suci yang memiliki keindahan atau nilai estetis. Resepsi ini juga ingin memperlihatkan bahwa keindahan-keindahan yang dijumpain di dalam al-Qur'an benar-benar menyau dan inheren. Artinya, al-Qur'an penuh dengan unsur-unsur puitis dan melodik yang mengalahkan karya sastra lainnya. Selain itu, al-Quran juga diterima secara estetis, yakni al-Quran dapat dibaca, ditulis, dinyanyikan (sari tilawah), dan ditampilkan secara estetik pula.

3. Resepsi Fungsional

Tipe resepsi ini ingin menunjukkan bahwa al-Qur'an memiliki posisi sebagai kitab yang diperuntukkan kepada manusia untuk digunakan dalam memperoleh tujuan tertentu. Dengan kata lain, manusia dalam konteks ini adalah subyek yang menerima khitāb, baik untuk merespon suatu kejadian atau mengarahkan manusia untuk melakukan sesuatu (humanitic hermeneutics). Berangat dari khitāb tersebut, manusia akan menggunakannya demi tujuan-tujuab tertentu dalam hidupnya. Pada akhirnya,

13 Akhmad Roja Zaman, 'Resepsi Al-Qur'an Di Pondok Pesantren Al-Hidayah Karangsuci Purwokerto', MAGHZA: Jurnal Ilmu Al-Qur'an Dan Tafsir, 4.1 (2019), 15-31

${ }^{14}$ Ahmad Rafiq, 'Pembacaan Yang Atomistik Terhadap Al-Qur'an; Antara Penyimpangan Dan Fungsi', Jurnal Studi Ilmu-Ilmu Al-Qur’an Dan Hadis, 5.1 (2004), hlm. 3. 
dari tujuan tersebut akan lahir sebuah dorongan untuk memunculkan sikap maupun perilaku dalam kehidupa sehari-hari.

Resepsi fungsional terhadap al-Qur'an pada akhirnya juga akan mewujudkan adanya fenomena sosial budaya di masyarakat. Artinya mereka membaca, menyuarakan, memperengarkan, menulis, memakai, dan meletakkan al-Quran di tempat-tempat tertentu. Dalam realisasinya bisa dilakukan secara individu maupun kolektif, rutin, temporer, insidental, bahkan tidak jarang akan memunculkan sistem sosial, adat, hukum dan politik. Sebagai contoh adalah tradisi yasinan, khataman, sima'an yang semuanya biasa dilakukan para santri di pondok pesantren sebagai bentuk resepsi al-Qur'an di tengah-tengah mereka.

\section{Metode Penelitian}

Penelitian ini merupakan penelitian kualitatif dengan memakai metode deskriptif. Moleong mengatakan bahwa penelitian kualitatif adalah penelitian yang memiliki tujuan untuk memahami fenomena apa saja yang dialami oleh subjek penelitian, seperti persepsi, tindakan, perilaku, motivasi, dan sebagainya secara komprehensif dengan cara deskripsi dalam bentuk kata-kata dalam suatu konteks dan metode alamiah. ${ }^{15}$ Penelitian ini berusaha mendeskripsikan resepsi al-Qur'an di Pondok Pesantren Al-Husna Sidorejo Pamotan Rembang. Tujuanya adalah untuk memperoleh deskripsi secara terperinci yang berkaitan dengan nilai-nilai atas resepsi tersebut.

Ada dua sumber data yang digunakan dalam penelitian ini, yaitu data primer dan data skunder. Data primer diperoleh melalui wawancara terhadap masyarakat Ponpes Al-Husna, yakni pengasuh, santri, pengurus, dan alumni Pondok Pesantren Al-Husna Sidorejo Pamotan Rembang dengan menggunakan beberapa sampel, yaitu pengasuh, sebagian santri, pengurus, dan alumni ponpes tersebut. Sementara data sekunder yang digunakan adalah dokumen, buku, jurnal, skripsi yang berkaitan dengan obyek yang diteliti.

Dalam teknik pengumpulan data, peneliti menggunakan metode observasi, interview dan dokumentasi. Dalam observasi, peneliti bertidak juga sebagai partisipan, yakni peneliti mengamati secara langsung kegiatan yang dijadikan obyek penelitian. Di beberapa kesempatan, peneliti juga mengikuti proses resepsi terhadap al-Quran di pondok tersebut. Dalam hal interview, peneliti melakukan interview tidak terencana. Artinya, peneliti melakukan tanya jawab dengan informan tanpa menyiapkan pertanyaan-pertanyaan yang formal dan ketat. Hal

\footnotetext{
${ }^{15}$ Lexy J Moleong, Metode Penelitian Kualitatif (Bandung: Remaja Rosdakarya, 2014, hlm. 6).
} 
ini dilakukan untuk memeroleh kenyamanan dalam wawancara dengan informan. Sementara dalam hal dokumentasi, peneliti melakukan dokumentasi melalui pengambilan gambar kegiatan yang berkaitan dengan resepsi warga pondok tersebut terhadap al-Qur'an.

Setelah data terkumpul, peneliti akan menganalisis data tersebut dengan cara (1) mengidentifikasi data sesuai dengan teori sosiologi makna Karl Mannheim, (2) mengklasifikasi data berdasarkan teori yang menjadi acuan, (3) menganalisis data dengan cara mencatat hasil wawancara yang berkaitan dengan teori, (4) menginterpretasi data yang sudah dianalisis sesuai dengan teori, (5) menyimpulkan hasil analisis sesuai data dengan cara menulis laporan.

\section{Pembahasan}

a. Seputar Pondok Pesantren Al-Husna Sidorejo Pamotan Rembang

Pondok Pesantren Al-Husna adalah pesantren didirikann oleh KH. Abdul Wahib Qohar pada tahun 2003. Lokasi pondok pesantren ini berada di desa Sidorejo kecamatan Pamotan Kabupaten Rembang. Bermula dari 6 santri yang diberikan KH. Ahmad Tamamuddin Munji selaku bapak mertua KH. Abdul Wahib Qohar yang awalnya bertempat di kamar dekat dapur ndalem, seiring berkembangnya waktu dan bertambahnya santri pada tahun 2003, KH Abdul Wahib Qohar membangun pesantren putra-putri.

Visi yang ingin dicapai pondok ini adalah 1) Mewujudkan pesantren yang mampu menghasilkan santri yang dapat menguasai disiplin ilmu keislaman, berakhlak mulia serta perduli pada sesama dan 2) Memantapkan iman dan taqwa untuk mencapai kebahagiaan hidup dunia dan akhirat berdasarkan al-Qur'an dan as-Sunah manhaj Ahlussunnah Wal Jama'ah.

Pada mulanya, tahun 1990 KH. Abdul Wahib menikah dan tinggal di Rembang tidak berencana mendirian pesantren. Beliau hanya ingin berhidmah dan membantu di pesantren milik mertua beliau, yaitu KH. Ach. Tammudin Munji di pesantren yang bernama Raudlotul Falah. Seperti yang diketahui di Rembang, mbah Tamam, sapaan akrab KH. Ach. Tamamuddin Munji, merupakan menantu dari mbah Ghozali, orang yang cukup disegani. Dikarenakan sejak dulu mbah Ghozali dikenal dengan sikap dan kecintaanya pada para kiai dan ulama, maka tidak lah heran jika besan-besannya adalah kiai, seperti mbah Munji Kajen, mbah Ridwan Sarang dan mbah Fathurrohman Senori. 
Mbah Tamam bin Munji yang asli kajen lalu merintis pesantren untuk pertama kalinya di desa njumput yang saat ini dikenal dengan desa Sidorejo. Pesantren itu bernama Ponpes Raudlotul Falah.

Tetapi seiring berjalannya waktu mbah Tamam mengutus KH. Abdul Wahib Qohar untuk merintis pesantren sendiri, meskipun awalnya menolak namun dengan diyakinkan dan niat birrul walidain, Kiai Wahib akhirnya melaksanakan perintah mbah Tamam untuk mendirikan pesantren sendiri. Karena keterbatasan lahan, maka pesantren dibangun di atas rumah dan dinamai dengan Raudlotul falah Al-Husna atau biasa disebut dengan Al-Husna.

Pesantren ini berbasik salaf yang fokus pada pengembangan kajian kitab kuning dan tariqat. Hal itu bisa dilihat dari karir pendidikan dan sanad keilmuan pengasuh di bawah ini.

1. Sayyid Muhammad Makkah

2. Syaikh Ismail Makkah

3. Syaikh Abdulloh Dardum Makkah

4. Syakh Abdulloh Ahlahji Makkah

5. Syaih Abdul Fatah Makkah

6. Syaikh Makky Makkah

7. KH. Muhammad Muslih Bandungsari

8. KH. R Abdul Karim Bandunsari

9. KH. Ma'ruf bandungsari

10. KH. Abdulloh Hafidz Kauman Rembang

11. KH. Abrur Rohim Ahmad Sarang

12. KH. Maimun Zubair Sarang Rembang

13. KH. A'wani sya'rowi Lodan

14. KH. Abdulloh Ubab Sarang

15. KH Ali Masfu' Sarang

16. KH. Wahab Hafidz kauman Rembang

17. KH. Fauzan Al Hafidz Rembang

Sekian banyak masyayih tersebut membuktikan bahwa konsentrasi Ponpes Al-Husna adalah dalam kajian keagamaan klasik dan bernuansa kitab kuning. Selain itu, di pones ini juga ditemukan kegiatan thariqah yang sudah berjalan puluhan tahun. Thariqah itu tidak lain adalah tahriqah Naqsanbandi Khalidiyyah yang merupakan tinggalan bapak mertua, KH. Ach. Tamamuddin Munji dan secara estafet dilanjutkan oleh sang menantu, KH. Abdul Wahib Qohar sampa saat ini.

b. Ragam Resepsi Al-Qur'an di Pondok Pesantren Al-Husna Sidorejo Pamotan Rembang 
Berdasarkan tipologi resepsi yang dijelaskan oleh Ahmad Rafiq, peneliti akan mengulas secara rinci tiga tipologi tersebut dalam konteks Pondok Pesantren Al-Husna Sidorejo Pamotan Rembang (selanjutnya dibaca Ponpes Al-Husna). Ketiga tipologi tersebut adalah : 1) Resepsi egsegegis dalam kajian kitab Tafsīr Jalālaīn, 2) Resepsi estetis kaligrafi di asrama Santri dan dalêm pengasuh, 3) Resepsi fungsional al-Qur'an dalam tradisi pembacaan surah-surah pilihan.

Kajian kitab Tafsīr Jalālaīn di Ponpes Al-Husna biasa dilaksanakan setiap hari kecuali hari Jum'at pagi. Kegiatan itu berlangsung jam 05.00-06.00 WIB. Kegiatan itu nyaris tidak pernah libur kecuali pengasuh ada $u d z u r$, seperti bepergian ke luar kota atau sakit $^{16}$. Kajian tersebut diawali dengan pembacaan shalawat Muhammadun secara bersamasama sembari santri menunggu kedatangan pengasuh ke majelis. Setelah pengasuh hadir, kajian kemudian dimulai dengan pembacaan hadrah dan fätihah. Seperti pada umumnya, kajian Tafsīr Jalālaīn dilakukan oleh pengasuh dengan model bandongan ${ }^{17}$ yang langsung bisa didengarkan para santri di majelis tersebut. Hanya saja, di mejelis ini dibuka sesi pertanyaan sebagai bentuk respon santri terhadap kajian kitab tersebut.

Secara sitematis, kajian kitab Tafsīr Jalālaīn di Ponpes Al-Husna ini terdiri dari tiga tahapan. Pertama, pengasuh membacakan ayat-ayat al-Qur'an yang akan menjadi topik pembahasan. Sintem yang dipakai dalam kajian ini adalah pengasuh atau kiai mengurutkan bacaan ayat demi ayat sesuia dengan urutan mushaf uśmāni. Setelah itu pengasuh memaknai kata demi kata dalam ururutan ayat sesuai dengan i'rāb dan tarkīb-nya. Fungsinya adalah untyk mempermudah santri dalam memahami teks tersebut.

Selanjutnya pengasuh memberikan penjelasan tentang penafsiran ayat-ayat tersebut. KH. Abdul Wahib Qohar selaku pengasuh sekaligus pengampu sering memberi catatancatatn tambahan yang terkait dengan topik yang dibahas, misalnya penyampaian sejarahsejarah dan kisah-kisah di luar teks Tafsīr Jalālaīn yang senada atau sesuai dengan isi, atau

${ }^{16}$ M. Azhar Jamaluddin, Wawancara Pengurus', Sidorejo, 18 Agustus 2020).

17 Tradisi pembelajaran di pesantren paling tidak dilakukan dengan tiga metode. Pertama adalah metode bandongan. Secara praktis, metode ini lebih menonjolkan keaktifan dan kreasi dari sang guru;kiai. Artinya, sang kiai membacakan kitab lalu menerangkan secara panjang lebar isi kitab tersebut. Kedua, metode sorogan. Metode ini lebih menitikberatkan pada santri yang membaca kitab lalu disimak dan didengar sekaligus diarahkan oleh kiai jika ditemukan kekurangfahaman santri. Pendek kata, santri membaca dan kiai menyimak dan mengoreksi bacaan santri. Ketiga, metode musyawarah. Metode ini juga menitikberatkan pada keaktifan santri dalam mengkaji sebuah kitab. Gambarannya adalah santri membaca kitab tertentu kemudian santri lain dipersilahkan untuk melakukn tanya-jawab dengan santri yang bertugas. Di sini, kiai atau ustadz bertugas sebagai pentashih dari diskusi yang dilakukan santri. 
pengasuh kerap kali memberi stimulus kepada para santri, berupa motovasi atau tembangtembang jawa yang dinyanyikan dengan shalawat untuk kemudian dinyanyikan bersama para santri.

Setelah pemaparan materi, pengasuh biasanya menawarkan kepada para santri supaya bertanya dan menanggapi paparan tersebut. Jika ditemukan pertanyaan, pengasuh langsung merespon dan menjawab pertanyaan-pertanyaan tersebut dengan penjelasan yang teliti dan luas penjabarannya. Kajian kitab Tafsìr Jalālaīn di Ponpes Al-Husna ini kemudian ditutup dengan salam dari pengasuh dan dilanjutkan membaca doa kafāratul majlīs dan lagu Yā Robbanā' Tarafnā secara komunal santri.

Selain itu, di Ponpes Al-Husna, keberadaan dan kehadiran al-Qur'an juga diresepsi secara estetis. Salah satu bentuk resepsi estetis ini bisa ditemukan orenamen-ornamen atau kaligrafi ayat suci al-Qur'an di dalêm pengasuh dan di asrama santri.

Salah satu ayat al-Qur'an yang ditempelkan di dalêm pengasuh adalah QS. Āli Imrān [3]: 79. Bahkan ada pula kaligrafi lengkap $30 \mathrm{Juz}$ dengan tulisan yang sangat kecil terpampang di tembok dalêm pengasuh. Kaligrafi tersebut terletak di ruang tamu bagian dalam dalêm pengasuh dengan ditulis dan dihias berbagai ornamen. Garis batas iluminasi kaligrafi tersebut menggunakan motof tumbuhan dengan perpaduan warna yang sesuai yang membuat kaligrafi tersebut semakin terlihat indah. Adapun kaligrafi yang ditemukan di asrama santri adalah QS. Al-Ḥasyr [59]: 18.

Kaligrafi pertama menggunakan model khat naskhi, sementara kaligrafi yang kedua menggunakan khat dīwāni. Khat dalam kaligrafi di Ponpes Al-Husna mempunyai bentuk huruf yang proporsional kaku dan persegi, juga persegi panjang. Dengan ukuran yang proporsional, kaligrafi ini terlihat indah memperelok asrama pesantren sekaligus dalêm pengasuh.

Selain kedua resepsi di atas, di Ponpes Al-Husna juga meresepsi keberadaan alQur'an secara fungsional. Praktik resepsi itu diwujudkan dengan adanya pembacaan surahsurah pilihan seperti surah Yāsīn, surah al-Wāqi'ah, dan surah al-Mulk.

Pembacaan surah Yāsīn rutin dilakukan santri selepas jama'ah shalat magrib. Pembacaan surah al-Wāqi'ah dilakukan setelah jama'ah isyā', sementara pembacaan surah al-Mulk dilakukan selepas jama'ah shalat subuh. Teknis pembacaan tiga surah tersebut seperti pada umumnya, yakni diawali dengan hadrah dan fătiḥah dan membaca aurād 
bilangan-bilangan tertentu. Setelah selesai pembacaan lalu dilakukan pembacaan doa oleh santri yang biasa ditunjuk oleh pengasuh ${ }^{18}$.

c. Resepsi Eternitas al-Qur'an dalam Tradisi Penjagaan al-Qur'an

Tipologi resepsi yang dijelaskan oleh Ahmad Rafiq tidak sepenuhnya mampu mengakomodir realitas dan fakta resepsi al-Qur'an di Ponpes Al-Husna. Artinya ketiga tiologi tersebut, baik egsegesis, esteti, maupun fungsional tidak bisa meng-cover kegiatan resepsi al-Qur'an dalam bentuk setoran al-Qur'an, baik secara bi al-nadzri, bi al-hifdzi, maupun sekedar murāja'ah.

Kegiatan atau praktik di atas merupakan salah satu upaya santri dalam menjaga orisinalitas dan otentitas al-Qur'an dengan cara membentuk karakter qura'ni pada setiap santri. Seperti pada umumnya, kegiatan tersebut diwujudkan dalam bentuk pemberian syahādah bagi mereka yang sudah khatam al-Qur'an, baik secara bi al-hifdzi (minimal juz Amma atau juz 30) atau bi al-nadzri. Tentu saja di antara tujuan pemberian syahādah tersebut adalah dalam rangka syi'ar Qur'ani dan bagian dari penjagaan al-Qur'an ${ }^{19}$.

Sejatinya resepsi eternitas secara substansial hampir sama dengan tipe resepsi fungsional. Hal yang membedakan antara keduanya adalah dalam hal ada atau tidaknya feedback. Resepsi fungsional mengaharapkan adanya feedback setelah meresapi al-Qur'an, sementara resepsi eternitas tidak demikian. Pembaca atau pelaku resepsi fungsional mengharapkan adanya keberkahan setelah membaca al-Qur'an atau surah-surah pilihan. Misalnya ketika membaca surah Yāsinn, santri Ponpes Al-Husna berharap supaya pahala pembacaan tersebut bisa bermanfaat untuk para leluhur mereka yang sudah mendahuluinya. Pembacaan surah al-Wāqi'ah misalnya terwujud resepsi dan feedback dari santri supaya dimudahkan dan diberkan rejeki yang barakah. begitu juga pembacaan surah al-Mulk, resepsi sekaligus feedback yang diharapkan adalah selamat dari siksa kubur.

Tujuan resepsi eternitas al-Qur'an di sini hanya untuk menjaga otentitas dan orisinalitas al-Qur'an dari masa ke masa. Bentuk penjagaan tersebut mereka afirmasikan sesuai QS. al-Hijr [15]: 9 yang menyatakan bahwa Allah akan senantiasa menjaga al-Qur'an sampai kapan pun. Itu artinya, resepsi eternitas merupakan bentuk ibadah atau ta'abbudi yang dilakukan oleh para santri Ponpes Al-Husna baik secara lisan, maupun tulisan.

${ }^{18}$ Asadatul Muna, Wawancara Santri, Sidorejo, 18 Agustus 2020.

${ }^{19}$ Nyai Hj. Anis Dzakiyyah, Wawancara Pengasuh, Sidorejo, 18 Agustus 2020. 
d. Makna Resepsi al-Qur'an di Pondok Pesantren Al-Husna Sidorejo Pamotan Rembang

Sebagaimana diyatakan oleh peneliti sebelumnya bahwa teori yang digunakan dalam penelitian ini adalah teori sosiologi makna Karl Mannheim. Selanjutnya teori tersebut digunakan untuk mengungkap makna resepsi al-Qur'an di Ponpes Al-Husna.

Karl Mannheim menyatakan bahwa di dalam perilaku manusia setidaknya terdapat tiga makna yang melekat di dalamnya. Pertama, makna objektif, yakni makna yang diperoleh dari konteks sosial di mana tindakan tersebut dilakukan atau berlangsung. Kedua, makna ekspresif, yakni makna yang ditunjukkan oleh aktor secara personal yang includ atau terintegrasi dalam praktik atau tradisi. Keriga, makna dokumenter, yakni makna yang bersal dari suatu tindakan namun diperoleh secara tersirat. Artinya, pelaku atau aktor melakukan sebuah tindakan tertentu yang tidak sepenuhnya sadar bahwa tindakan yang diaplikasikan tersebut menunjukkan budaya secara keseluruhan. ${ }^{20}$

a) Makna Objektif

Makna objektif yang terdapat dalam ragam resepsi al-Qur'an di Ponpes AlHusna adalah bentuk atau bagian dari simbolisasi ketaatan dan keta'dziman terhadap peraturan pondok yang telah ditetapkan, di samping juga arahan-arahan yang diberikan pengasuh kepada para santri. Sikap patuh, ta'dzim, ta'at, dan tunduk kepada pengasuh merupakan karakteristik sebuah lembaga keagamaan yang bernama pesantren. Sehingga dikatakan bahwa pesantren merupakan wadah atau tempat yang digunakan para kiai untuk membangun sebuah patonasi. Dari sistem patronasi ini kemudian pesantren mampu membuktikan bahwa lembaga keagamaan tersebut mampu bertahan sampai saat ini. $^{21}$

Dalam konteks kajian kitab Tafsìr Jalālaīn, kajian kitab tersebut hanya diperbolehkan bagi santri yang sudah hatam al-Qur'an 30 Juz bi al-Nadzri dan sudah kelas minimal 3 Tsanāwiyyah di madrasah diniyyah ${ }^{22}$. Dari hasil wawancara pada santri yang mengikuti kajian tersebut, nyaris ditemukan jawaban yang sama bahwa mereka melakukan kegiatan tersebut sebagai bentuk kepatuhan pada peraturan pondok

${ }^{20}$ Gregory Baum, Agama Dalam Bayang-Bayang Irelativisme: Sebuah Analisis Sosiologi Pengetahuan Karl Mannheim Tentang Sintesa Kebenaran Historis-Normatif, Ter. Achmad Mustajib et. Al. (Yogyakarta: PT. Tiara Wacana, 1999), hlm. 15-16.

${ }^{21}$ Syamsul Ma'arif, 'Pola Hubungan Patron-Client Kiai Dan Santri Di Pesantren', Ta'dib: Journal of Islamic Education (Jurnal Pendidikan Islam), 15.2 (2010), 273-96.

${ }^{22}$ Muhammad Ridlwan, Wawancara Santri, Sidorejo, 18 Agustus 2020. 
pesantren. Kepatuhan, ketakdziman, dan sikap hormat merupakan salah satu nilai pertama yang ditanamkan pada santri ${ }^{23}$.

Akhlak yang dibangun ini merupakan cara yang dilakukan santri untuk menghormati guru. Mereka sadar bahwa kiai adalah estafet para nabi, warasiah alanbiya $\bar{a}^{\prime}$, dan bahwa ridha seorang kiai itu sangat penting untuk keberlangsungan hidup santri. Ada adagium Arab yang populer dan sangat dimungkinkan mereka pahami.

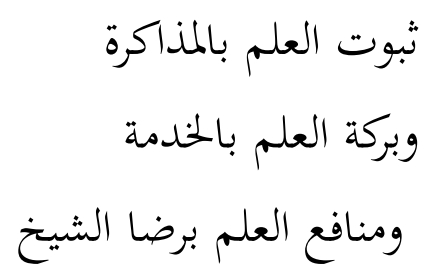

"Ketetapan ilmu diperoleh dengan belajar, ilmu yang barokah diperoleh melalui dedikasi tinggi (khidmah), dan ilmu yang bermanfaat diperoleh melalui ridha dari sang guru"

Potongan adagium terakhir menjadi nilai terpenting bagi santri, bahwa apapun perbuatan yang dilakukan santri semestinya mendapatkan izin dan ridha terlebih dahulu dari kiainya. Hal ini pula lah yang menjadi habitus santri dalam melakukan kajian kitab Tafsīr Jalālaīn, yakni menjalankan sistem yang sudah menjadi keyakinan masingmasing santri.

b) Makna Ekspresif

Varian resepsi al-Qur'an yang ditemukan di Ponpes Al-Husna Sidorejo menjadikan beragam pula makna ekspresif yang diperoleh, tentu keberagaman tersebut berasal dari pelaku atau aktor yang berbeda beda. Dalam konteks kajian kitab Tafsìr Jalälaīn, dari berbagai makna ekspresi, setidaknya ada tiga besar makna ekspresif yang ditemukan di Ponpes Al-Husna. Pertama, santri ingin menambah khazanah keilmuan terhadap penafsiran al-Quran. Kedua, kegiatan tersebut merupakan bentuk ikhtiar menjadi sebaik-baiknya manusia. Ketiga, kegiatan tersebut sebagai upaya menghindari kesombongan dalam arti kalau dirasa sudah pintar maka diperbolehkan untuk tidak mengaji ${ }^{24}$.

Bagi pengasuh sekaligus pengampu, kajian kitab Tafsīr Jalālaīn merupakan bentuk apresiatif umai Islam terhadap karya-karya ulama klasik. Tafsir merupakan salah

\footnotetext{
${ }^{23}$ Alviatun Nikmah, Wawancara Santri, Sidorejo, 18 Agustus 2020.

${ }^{24}$ Muhammad Murtaghib Fillah, 'Wawancara Santri' (Sidorejo, 2020).
} 
satu pintu untuk bisa memahami isi al-Qur'an. Dengan mempelajari tafsir, santri akan mampu membuka rahasia makna-makan al-Qur'an, baik dari sisi ubüdiyyah, mu'āmalah, dan meneladani kisah-kisah terdahulu untukdijadikan i'tibār. Dengan demikian, santri memiliki pemahaman yang komprehensif tentang isi dan makna dalam al-Qur'an. Sangat tidak diharapkan bahwa santri memahami al-Qur'an tanpa melalui tafsur-tafsir karya ulama-ulama terdahulu, sehingga yang terjadi adalah pemahaman yang literal dan rigit ${ }^{25}$.

Sementara kaitannya dengan resepsi estetis al-Qur'an yang teraplikasikan dalam kaligrafi yang terdapat di Ponpes Al-Husna, kaligrafi tersebut merupakan simbol dari spiritualitas, yakni tidak hanya sebatas keindahan yang melingkupi pesantren tetapi juga untuk memberi pencerahan bagi yang membaca. Ini lah yang paling penting. Harapannya adalah ketika seseorang membaca kaligrafi tersebut, hati akan tergugah dan memberi peringatan untuk pembaca ${ }^{26}$. Hal tersebut bisa dilihat misalnya kaligrafi QS. Āli Imrān [3]: 79 di dalêm sebagai upaya bagi siapa pun pembaca akan pentingnya ikhlas dalam belajar maupun mengajar. Keduanya merupakan syarat mutlak keberkahan yang nanti akan diterima oleh kedua belah pihak, yakni guru/kiai atau pun santri. Sementara kaligrafi yang berada di asrama pesantren, QS. al-Ḥasyr [59]: 18 merupakan upaya untuk mengingatkan para santri supaya senatiasa instrospeksi diri, ikhtiyāt, berhati-hati dalam bertindak, dan juga bertaqwa kepada Allah. Hal itu dikarenakan Allah SWT. senantiasa menjadi Dzat Yang Mahateliti atas segala tindakan manusia, termasuk santri.

c) Makna Dokumenter

Makna dokumenter merupakan makna implisit atau makna tersirat dari tindakan tertentu. Artinya setiap tindakan yang dilakukan aktor atau pelaku tidak sepenuhnya disadari bahwa aksi atau sindakan tersebut merupakan bagian dari ekspresi budaya yang menyeluruh. Dalam konteks kajian kitab Tafsīr Jalālaīn, dari responden diketahui bahwa alasan diadakannya kegiatan rutin tersebut merupakan bagian dari upaya menjaga tradisi yang sudah berjalan secara turun-temurun ${ }^{27}$. Artinya, secara tidak langsung responden telah mengafirmasi bahwa kajian kitab Tafsīr Jalālaīn merupakan

${ }^{25}$ KH. Abdul Wahib Qohar, Wawancara Pengasuh Dan Pengampu Tafsir Jalalain, Sidorejo, 18 Agustus 2020.

${ }^{26} \mathrm{Nyai} \mathrm{Hj}$. Anis Dzakiyyah, Wawancara Pengasuh, Sidorejo, 18 Agustus 2020.

${ }^{27}$ Munhaji, Wawancara Santri, Sidorejo, 18 Aguatus 2020. 
simbol dari pada hakikat ilmu di kalangan pesantren. Ilmu dianggap oleh masyarakat pesantren, sebagaimana yang dikatakan oleh Mas'udi, sebagai sesuatu yang diperoleh melalui pewarisan, pengalihan, transmisi, dan bukan suatu hal yang diciptakan ${ }^{28}$.

Dengan demikian, ada dua hal yang menjadi konsekuensi dalam konteks kajian kitab Tafsīr Jalālaīn. Pertama, terwujudnya homogenitas atau keseragaman dalam kajian kitab Tafsìr Jalālaīn di setiap pondok pesantren. Hampir dikatakan secara mayoritas setiap pesantren mengakaji kitab Tafsìr Jalālaīn walaupun dengan ungkapan atau teknis yang berbeda. Kedua, terwujudnya stratifikasi keilmuan, yakni kitab Tafsir Jalālaīn merupakan salah satu karya ulama terdahulu yang menjadi patokan dan sentral. Sang kiai hanya sekedar memberi ulasan atau keterangan dari kitab tersebut. Dia bentindak sekedar instrumen, bukan sebagai orang yang kapasitasnya memberi evaluasi $^{29}$. Sehingga dapat disimpulkan bahwa kajian kitab Tafsīr Jalālaīn di Ponpes Al-Husna sejatinya merupakan wujud dari kebudayaan yang menyeluruh. Dari dulu hingga sekarang, kajian kitab Tafsīr Jalālaīn sudah ada dan dilestarikan hingga saat ini di berbagai pesantren maupun di majelis-majelis taklim lain.

Hal lain yang sudah menjadi budaya menyeluruh, namun tidak disadari secara langsung adalah resepsi estetis al-Qur'an dalam bentuk kaligrafi. Seni budaya Islam, dalam hal ini seni kaligrafi merupakan seni yang sudah ada sejak zaman dahulu ${ }^{30}$. Hanya saja para pelaku atau aktor tidak menyadari keberadaan seni tersebut. Asal-asul seni kaligrafi setidaknya didasari pada dua hal. Pertama pada data-data historis yang bisa dibuktikan validitasnya. Kedua pada keyakinan mistis yang tidak jelas ujung pangkalnya. Namun demikian, seni kaligrafi tidak lah muncul tiba-tiba di ruang kosong. Tentunya ada tahapan dan proses panjang yang melingkupinya. Setiap jenis tulisan atau khat melalui berbagai eksperimen dan prosen yang intensif selama bertahun-tahun sampai membentuk tulisan seperti sekarang, dan bahkan akan terus berkembang.

Dalam konteks pemeliharaan al-Qur'an yang dilakukan Ponpes Al-Husna, sejatinya tindakan tersebut merupakan bentuk kebudayaan yang komprehensif atau menyeluruh. Gambaran paring awal bentuk pemeliharaan al-Qur'an bisa ditengok

\footnotetext{
${ }^{28}$ Rosihon Anwar, Dadang Darmawan, and Cucu Setiawan, 'Kajian Kitab Tafsir Dalam Jaringan Pesantren Di Jawa Barat', Wawasan: Jurnal Ilmiah Agama Dan Sosial Budaya, 1.1 (2016), 56-69.

${ }^{29}$ Anwar, Darmawan, and Setiawan, 'Kajian Kitab Tafsir Dalam Jaringan Pesantren Di Jawa Barat', hlm. 59.

${ }^{30}$ Rispul, 'Kaligrafi Arab Sebagai Karya Seni’, Tsaqafa, Jurnal Kajian Seni Budaya Islam, 1.1 (2012), 9-18.
} 
sejarah dan riwayat sejak zaman Nabi dan para sahabat. Al-Qur'an secara khusus dipelihara dan dijaga para sahabat dengan cara dihafalkan. Bukti sejarah menyatakan, walaupun tidak semua, namun mayoritas sahabat merupakan penghafal al-Qur'an, misalnya Zaid bin Tsabit, Ibnu Abbas, Usman bin Affan, dan Ali bin Abi Thalib ${ }^{31}$.

Bentuk pemeliharaan sahabat terhadap al-Qur'an merupakan embrio dan cikal bakal munculnya kodifikasi al-Qur'an secara menyeluruh. Walaupun secara sosialhistoris dijelaskan bahwa bentuk eternitas dan preservasi para sahabat dilakukan melalui hafalan, sejatinya tidak beberapa sahabat mencoba menuliskan al-Qur'an ke dalam bentuk tulisan. Tadisi tersebut kemudian diteruskan oleh generasi setelahnya, yakni tābi'īn, tābi tābi'īn, ulama-ulama setelahnya dan bahkan sampai saat ini banyak ditemukan para penghafal al-Qur'an dan penjaga al-Qur'an melalui tulisan, baik kaligrafi manual maupun melalui mesin cetak. Hal ini pula lah yang dilakukan oleh warga Ponpes Al-Husna Sidorejo Pamotan Rembang.

Praktik resepsi eternitas al-Qur'an di Ponpes Al-Husna sejatinya merupakan bentuk kebudayaan yang secara tidak sadar dipratikkan oleh lembaga keagamaan lainnya. Misalnya saja, banyak ditemukan pesantren-pesantren yang memiliki progam khusus hafalan al-Qur'an (tahfidz), sebut saja beberapa di antara Pondok Pesantren Yanbū al-Qur'an Kudus, Pondok Pesantren al-Munawwir Krapyak dengan segala kompleknya, Pondok Pesantren al-Qur'an Betengan, Pondok Pesantren Al-Barakah Lirboyo Kediri dan masih sangat banyak untuk disebutkan satu per satu. Keseluruhan pondok pesantren tersebut biasanya akan memberikan syahādah bagi para santri yang sudah mengkhatamkan al-Qur'an di acara wisuda di salah satu acara tahunan.

\section{E. Kesimpulan}

Berdasarkan penelitian yang dilakukan peneliti mengenai resepsi al-Qur'an di Pondok Pesantren Al-Husna Sidorejo Pamotan Rembang, maka dapat disimpulkan sebagai berikut : 1) Tipologi atau varian praktik resepsi al-Qur'an yang ada di Ponpes Al-Husna dikelompokkan menjadi empat varian, yakni a) resepsi egsegesis yang diwujudkan dalam bentuk kajian kitab Tafsīr Jalālaīn, b) resepsi estetis dalam bentuk kaligrafi yang diambil dari ayat-ayat di dalam

${ }^{31}$ M Hanafiah Lubis, 'Efektifitas Pembelaran Tahfizhil Al-Quran Dalam Meningkatkan Hafalan Santri Di Islamic Centre Sumatera Utara', ANSIRU PAI: Pengembangan Profesi Guru Pendidikan Agama Islam, 1.2 (2017), 6773. 
al-Qur'an yang bertempat di dalêm pengasuh dan di asrama santri, c) resepsi fungsional yang dimanifestasikan dalam tradisi pembacaan surah-surah pilihan, Yāsīn, al-Wāqi'ah, dan al-Mulk, dan 4) resepsi eternitas al-Qur'an yang diwujudkan dalam beragam bentuk kegiatan penjagaan al-Qur'an, seperti hafalan, setoran pembacaan al-Qur'an, dan murāja'ah al-Qur'an.

Sementara makna yang melekat dari ragam resepsi al-Qur'an di Pondok Pesantren AlHusna Sidorejo Pamotan Rembang, dengan berdasarkan teori sosiologi Karl Mannheim, terbagi menjadi tiga makna. Makna objektif didapatkan bahwa ragam resepsi al-Qur'an di Ponpes AlHusna merupakan bagian dari simbol ketakdziman dan kepatuhan terhadap peraturan pondok. Makna ekpresif yang ditemukan adalah adanya internalisasi dengan hal-hal positif melalui proses pembelajaran al-Qur'an yang berkelanjutan di pondok tersebut. Sementara makna dokumenter yang ditemukan adalah adanya kontekstualisasi lokal dari sistem kebudayaan secara menyeluruh.

\section{Daftar Pustaka}

Al-Baihaqi, Dalail Al-Nubuwwah (Kairo: Dar al-Kutub al-Ilmiyyah, 1986), II

Anwar, Rosihon, Dadang Darmawan, and Cucu Setiawan, 'Kajian Kitab Tafsir Dalam Jaringan Pesantren Di Jawa Barat', Wawasan: Jurnal Ilmiah Agama Dan Sosial Budaya, 1.1 (2016), 56-69

Baum, Gregory, Agama Dalam Bayang-Bayang Irelativisme: Sebuah Analisis Sosiologi Pengetahuan Karl Mannheim Tentang Sintesa Kebenaran Historis-Normatif, Ter. Achmad Mustajib et. Al. (Yogyakarta: PT. Tiara Wacana, 1999)

Dzakiyyah, Nyai Hj. Anis, Wawancara Pengasuh (Sidorejo, 2020)

Esack, Farid, The Qur'an: A Short Introduction (England: Oneworld, 2002)

Fatah, Abdul Fatah, 'Living Qur'an: Tradisi Wirid Al-Ma'tsūrāt Di Smait Abu Bakar Boarding School Kulon Progo', Jurnal At-Tibyan: Jurnal Ilmu Alqur'an Dan Tafsir, 5.1 (2020), 1-19

Fathurrosyid, Fathurrosyid, 'Tipologi Ideologi Resepsi Al Quran Di Kalangan Masyarakat Sumenep Madura', EL HARAKAH Jurnal Budaya Islam, 17.2 (2016), 218-39

Fillah, Muhammad Murtaghib, 'Wawancara Santri' (Sidorejo, 2020)

Huda, Nur, 'Observasi Dan Pengamatan' (Sidorejo, 2020)

— 'Uslub Al-Tikrar Fi Surah Al-Mu'awwidzatain', Indonesian Journal of Islamic Literature and Muslim Society, 5.1 (2020), 1-13

Iser, Wolfgang, The Act of Reading : A Theory of Aesthetic Response (Baltimore: John Hopkins University Press, 1979)

Jamaluddin, M. Azhar, 'Wawancara Pengurus' (Sidorejo, 2020)

Lubis, M Hanafiah, 'Efektifitas Pembelaran Tahfizhil Al-Quran Dalam Meningkatkan Hafalan Santri Di Islamic Centre Sumatera Utara', ANSIRU PAI: Pengembangan Profesi Guru Pendidikan Agama Islam, 1.2 (2017), 67-73

Ma'arif, Syamsul, 'Pola Hubungan Patron-Client Kiai Dan Santri Di Pesantren', Ta'dib: Journal of Islamic Education (Jurnal Pendidikan Islam), 15.2 (2010), 273-96

Maghfiroh, Elly, 'Living Qur'an : Khataman Sebagai Upaya Santri Dalam Melestarikan Al-Qur'an', 
Hermeneutik: Jurnal Ilmu Al-Qur'an Dan Tafsir, 11.1 (2017), 109-27

Moleong, Lexy J, Metode Penelitian Kualitatif (Bandung: Remaja Rosdakarya, 2014)

Muna, Asadatul, 'Wawancara Santri' (Sidorejo, 2020)

Munhaji, Wawancara Santri (Sidorejo, 2020)

Nikmah, Alviatun, 'Wawancara Santri' (Sidorejo, 2020)

Pradopo, Rachmad Djoko, Beberapa Teori Sastra : Metode Sastra Dan Penerapannya (Yogyakarta: Pustaka Pelajar, 2007)

Pujiono, 'Wawancara Santri' (Sidorejo, 2020)

Qohar, KH. Abdul Wahib, 'Wawancara Pengasuh Dan Pengampu Tafsir Jalalain' (Sidorejo, 2020)

Rafiq, Ahmad, 'Pembacaan Yang Atomistik Terhadap Al-Qur'an; Antara Penyimpangan Dan Fungsi’, Jurnal Studi Ilmu-Ilmu Al-Qur'an Dan Hadis, 5.1 (2004)

Ratna, Nyoman Kuta, Teori Dan Metode Teknik Penelitian Sastra, 8th edn (Yogyakarta: Pustaka Pelajar, 2011)

Ridlwan, Muhammad, 'Wawancara Santri' (Sidorejo, 2020)

Rispul, 'Kaligrafi Arab Sebagai Karya Seni', Tsaqafa, Jurnal Kajian Seni Budaya Islam, 1.1 (2012), 9-18

Shobahah, Luthfiatus, 'Praktik Pembacaan Yasin Fadilah Di Masyarakat Perspektif Living Qur'an Dan Analisis Perubahan Sosial (Studi Kasus Di Majelis Taklim Al-Muthmainnah Desa Lemahabang Kulon, Kec. Lemahabang, Kab. Cirebon)', Diya Al-Afkar: Jurnal Studi AlQuran Dan Al-Hadis, 5.02 (2017), 315-38

Zaman, Akhmad Roja, 'Resepsi Al-Qur'an Di Pondok Pesantren Al-Hidayah Karangsuci Purwokerto', MAGHZA: Jurnal Ilmu Al-Qur'an Dan Tafsir, 4.1 (2019), 15-31 <https://doi.org/https://doi.org/10.24090/maghza.v4i1.2142> 